\title{
Mineral composition and growth of babycorn under swine wastewater combined with chemical fertilization
}

\author{
Adriana M. Meneghetti ${ }^{1}$, Lúcia H. P. Nóbrega ${ }^{2}$, Silvio C. Sampaio ${ }^{3} \&$ Rafael G. Ferques ${ }^{4}$
}

\begin{abstract}
RESU M O
The objective of this study was to evaluate the application of wastewater from swine manure (ARS) and chemical fertilization on foliar concentrations of macronutrients and micronutrients, and its relationship with the growth of babycorn. An experiment was conducted in completely randomized design with eight treatments and three replications in $4 \times 2$ factorial arrangement, which consisted of the application of four doses of swine wastewater $\left(0,40,80\right.$ and $\left.120 \mathrm{~kg} \mathrm{~N} \mathrm{ha}^{-1}\right)$ and two levels of chemical fertilization ( 0 and 40 $\left.\mathrm{kg} \mathrm{ha}^{-1}\right)$. The results indicated that the increase in fertilization using swine wastewater manure resulted in significant differences for babycorn's foliar concentrations of $\mathrm{N}$ and $\mathrm{P}$, promoting levels below the adequate for $\mathrm{N}$ and $\mathrm{K}$, appropriate levels of $\mathrm{Cu}, \mathrm{Zn}, \mathrm{Mn}$ and $\mathrm{Fe}$, and levels above the adequate for $\mathrm{P}, \mathrm{Ca}$, $\mathrm{Mg}$ and $\mathrm{S}$. For growth variables, results indicated significant differences and the increased use of fertilizer with swine wastewater promoted higher plant height, leaf area, leaf area index, number of leaves per plant and absolute growth rate.
\end{abstract}

Key words: Zea mays L., leaf content, nutrients

\section{Composição mineral e crescimento do minimilho sob água residuária de suinocultura combinada com adubação química}

\begin{abstract}
A B STRACT
O bjetivou-se, com este trabalho, avaliar a aplicação de águas residuárias de suinocultura (ARS) e adubação química sobre os teores foliares de macronutrientes e micronutrientes e sua relação com o crescimento do minimilho. Conduziu-se um experimento em delineamento inteiramente casualizado, com oito tratamentos e três repetições dispostos em esquema fatorial $4 \times 2$, os quais consistiram da aplicação de quatro doses de água residuária de suinocultura $\left(0,40,80\right.$ e $120 \mathrm{~kg} \mathrm{ha}^{-1}$ de $\left.\mathrm{N}\right)$ e duas doses de adubação química (0 e $40 \mathrm{~kg} \mathrm{ha}^{-1}$ ). O s resultados indicaram que o incremento na adubação com uso de águas residuárias de suinocultura favoreceu diferenças significativas para as concentrações foliares no minimilho para $\mathrm{N}$ e $\mathrm{P}$, proporcionou teores abaixo dos adequados para $\mathrm{N}$ e $\mathrm{K}$, teores adequados de $\mathrm{Cu}, \mathrm{Zn}, \mathrm{Mn}$ e Fe e teores acima dos adequados para $\mathrm{P}, \mathrm{Ca}, \mathrm{Mg}$ e $\mathrm{S}$. Para as variáveis de crescimento os resultados indicaram que houve diferenças significativas e que o incremento da adubação com uso de ARS proporcionou maiores estaturas de plantas, área foliar, índice de área foliar, número de folhas por planta e taxa de crescimento absoluto.
\end{abstract}

Palavras-chave: Zea mays L., teores foliares, nutrientes

\footnotetext{
${ }_{1}^{1}$ Post-doctoral fellow, UNIOESTE - PN PD/CAPES. Rua U niversitária 2069, CEP 85819-110. Cascavel, PR. Phone: + 55 (45) $3096-3441$ E-mail: adri@innet.com.br

2 UNIOESTE/CASCAVEL/CCET/Programa de Pós-Graduação em Engenharia Agrícola - PGEAGRI/SBA. Phone: + 55 (45) 3220-3195. E-mail: lucia.nobrega@unioeste.br

UNIOESTE/CASCAVEL/CCET/PGEAGRI/RHESA, Phone: + 55 (45) 3220-7412. E-mail: silvio.sampaio@unioeste.br

${ }^{4}$ G raduate student, U NIO ESTE/CASCAVEL. Prof. Universidade Paranaense - U NIPAR, Phone: + 55 (45) 3096-3441. E-mail: ferques@unipar.br
} 


\section{INTRODUCTION}

The environmental impact of using sources of nutrients applied in medium and long-term periods can be evaluated using embedded attributes, which take into account harmful or beneficial use of waste as source of nutrients to plants when applied in soil management systems (Pandolfo et al., 2008).

Agricultural recycling of swine manure is highlighted as important technological alternative, which allows mineral elements and organic matter contained in manure excreted by animals returning to the ground, serving as nutrients to plants, bringing benefits to the chemical, physical and biological properties of soils, while the problem of soil and water contamination is minimized (Seidel et al., 2010).

The knowledge of absorption and accumulation of nutrients in the development stages of maize crop allows determining the times when elements are more required and advising deficiencies corrections that may occur during its development, and estimating the rates that will be exported by grains harvest or forage, and those that may be returned to the soil by crop residues (Pinho et al., 2009).

The nutritional needs of any plant are determined by the amount of nutrients it extracts during its cycle (Büll, 1993) and vary depending on the plant production and its interaction with the environment. The determination of nutritional requirements is based on the expectation that there is correlation between the availability of nutrients in the soil, foliar content and productivity. Studies have shown that application of wastewater increased the concentration of macro and micronutrients in various crops such as cotton (Ferreira et al., 2005) and maize (Prior et al., 2009), the increase being influenced by the concentration of nutrients in the wastewater.

An alternative that allows for the use of waste, minimizing its impact on the environment is aimed, since the intensification of technified swine manure, by being a waste concentrator activity, possessing high pollutant load to the soil, air and water, and also as in some Brazilian regions a considerable increase in the wastewater production from swine manure (ARS) - depending on the type of management - have become a major source of contamination (Smanhotto et al., 2010).

The alternative use as fertilizer appears since the ARS has constituents which added to the soil provides nutrients to plants and can be absorbed after mineralization, but if in undesirable levels may lead to contamination of soil, water and plant. In addition to the waste fate, it is possible to reduce the use of chemical fertilizers, more frequent water availability, improvement of soil quality and increased crop yields.

In babycorn crops, the time of land use and dependence on fertilization are less demanding factors than that corn crop in grains or silage; thus, high amounts of fertilizer will not be translated into productivity, but there is the compensation for straw use for subsequent crops (Meneghetti et al., 2008a,b). The baby corn needs nutrients readily available, and the ARS are rich in macro and micronutrients and have most of them easily mineralizable, except potassium and sodium, which do not depend on mineralization since they are not associated with organic material.
In relation to fertilization and nutritional status related to culture, aspects highlighted included: removal of nutrients as function of time and development, amount and form of absorption and productivity; concerning to soil, available elements and their interactions with chemical, physical and biological characteristics, interactions with crop's nutritional requirements; and fertilizers, economic aspects, physical and chemical characteristics, timing and form of application and mobility in soil (Vasconcellos et al., 2001). As there is increase in the slurry applied dose, especially from 40 to $80 \mathrm{~m}^{3} \mathrm{ha}^{-1}$, there is decrease in the uptake efficiency by plants. Thus, doses above $40 \mathrm{~m}^{3} \mathrm{ha}^{-1}$ in addition to being less efficient under the nutritional point of view, may pose a risk of contamination to surface and subsurface waters by infiltration of nutrients in the studied soil profile (Durigon et al., 2002).

The swine manure is made up of elements that both promote the development of plants and cause environmental damage. Hence the importance of assessing the amount of waste that could be added to the soil and for how long, with no negative consequences to the soil as ionic imbalance, phytotoxicity to plants, atmosphere pollution by evaporation and contamination of surface and subsurface waters by leaching so that systems fertilized with this waste become self-sustaining. The use of swine wastewater has many benefits; however, regarding the dosage of application of these waters, there is need for discussion. Thus, this study aimed to investigate the babycorn's nutritional status and evaluate its growth, under application of swine wastewater combined with chemical fertilizer in the sixth application cycle.

\section{Material AND METHODS}

The experiment was conducted at the Experimental Center of Agricultural Engineering - NEEA, the Center of Exact Sciences and Technology at the State University of West Paraná - Campus Cascavel, PR, located at the 101 km BR 467 towards Cascavel - Toledo, between the coordinates $24^{\circ} 48^{\prime}$ south latitude and $53^{\circ} 26^{\prime}$ west longitude and $760 \mathrm{~m}$ altitude from October to December 2008. The climate is humid subtropical (Cfa), with $1.800 \mathrm{~mm}$ average annual rainfall. The soil type, according to the classification of EMBRAPA (2006), is characterized as typical Oxisol (clayey). Experiments with application of swine wastewater are conducted in this area and this was the sixth consecutive cycle, with sequence of maize/ soybean/oats/soybean/oats and babycorn.

Treatments were distributed in a completely randomized design in 4 x 2 factorial arrangement with three replications, consisting of swine wastewater (ARS) doses $(0,115.20 ; 230.40$ and 345.60 $\mathrm{m}^{3} \mathrm{ha}^{-1}$ or equivalent to $0 ; 40 ; 80$ and $120 \mathrm{~kg} \mathrm{ha}^{-1} \mathrm{~N}$ ) and chemical fertilizer (AD) levels (equivalent to 0 and $40 \mathrm{~kg} \mathrm{ha}^{-1} \mathrm{~N}$ ).

The average chemical characteristics of soil at $0-60 \mathrm{~cm}$ depth per treatment at the beginning of the experiment are presented in Table 1.

The used ARS was collected in a rural property of an integrated biosystem for waste treatment and breeding 
Table 1. Soil's chemical characterization before swine wastewater application for $\mathrm{pH}$ values, organic matter (OM), total nitrogen ( $\mathrm{N}$ total), potential acidity $\left(\mathrm{H}^{+}+\mathrm{Al}^{+3}\right)$, total bases $(\mathrm{SB})$, cation exchange capacity $(\mathrm{CEC})$, calcium $\left(\mathrm{Ca}^{+2}\right)$, magnesium $\left(\mathrm{M} \mathrm{g}^{+2}\right)$, potassium $\left(\mathrm{K}^{+}\right)$, phosphorus $(\mathrm{P})$ and base saturation $(\mathrm{V})$

\begin{tabular}{|c|c|c|c|c|c|c|c|c|c|c|c|}
\hline \multirow{2}{*}{$\mathrm{T}^{*}$} & \multirow{2}{*}{$\begin{array}{c}\mathrm{pH} \\
\left(\mathrm{CaCl}_{2}\right)\end{array}$} & MO & $\mathbf{N}_{\text {total }}$ & $\mathrm{H}+\mathrm{Al}^{+3}$ & SB & CTC & $\mathrm{Ca}$ & $\mathrm{Mg}$ & K & \multirow{2}{*}{$\begin{array}{c}P \\
\mathrm{mg} \mathrm{dm}\end{array}$} & \multirow{2}{*}{$\begin{array}{c}\mathbf{V} \\
(\%)\end{array}$} \\
\hline & & \multicolumn{2}{|c|}{$\mathrm{g} \mathrm{dm}^{-3}$} & \multicolumn{6}{|c|}{$\mathrm{cmol}_{\mathrm{c}} \mathrm{dm}^{-3}$} & & \\
\hline 1 & 6.17 & 19.95 & 1.00 & 3.32 & 9.82 & 13.14 & 3.29 & 2.88 & 0.31 & 8.80 & 75.15 \\
\hline 2 & 6.20 & 22.15 & 1.11 & 3.30 & 9.36 & 12.66 & 5.01 & 2.10 & 0.24 & 7.23 & 74.02 \\
\hline 3 & 6.27 & 23.12 & 1.16 & 3.07 & 8.61 & 11.67 & 3.21 & 2.47 & 0.26 & 3.50 & 73.82 \\
\hline 4 & 6.37 & 21.99 & 1.10 & 3.04 & 8.60 & 11.64 & 3.66 & 2.39 & 0.22 & 5.83 & 73.70 \\
\hline 5 & 6.73 & 22.46 & 1.12 & 2.34 & 10.95 & 13.29 & 5.06 & 2.54 & 0.36 & 7.77 & 81.87 \\
\hline 6 & 6.27 & 23.60 & 1.18 & 2.98 & 10.10 & 13.08 & 4.08 & 2.78 & 0.24 & 5.73 & 77.06 \\
\hline 7 & 6.47 & 24.32 & 1.22 & 2.80 & 9.91 & 12.71 & 4.38 & 2.56 & 0.31 & 7.90 & 77.32 \\
\hline 8 & 6.43 & 21.71 & 1.09 & 2.84 & 10.30 & 13.13 & 4.64 & 2.66 & 0.33 & 6.33 & 77.70 \\
\hline
\end{tabular}

system in a piglet production unit (PPU). The ARS collection site was in the pipe exit, after passing through the biodigester followed by sedimentation tank and stabilization pond. ARS characteristics used in the experiment are presented in Table 2 .

Table 2. Physico-chemical characterization of swine wastew ater (ARS) used in the experiment

\begin{tabular}{lr}
\hline Parameters & Result \\
pH $\left(\mathrm{CaCl}_{2}\right)$ & 7.92 \\
Total nitrogen $\left(\mathrm{mg} \mathrm{L}^{-1}\right)$ & 338.80 \\
Nitrate $\left(\mathrm{mg} \mathrm{L}^{-1}\right)$ & 8.00 \\
Nitrite $\left(\mathrm{mg} \mathrm{L}^{-1}\right)$ & 0.40 \\
Total phosphorus $\left(\mathrm{mg} \mathrm{L}^{-1}\right)$ & 21.13 \\
Potassium $\left(\mathrm{mg} \mathrm{L}^{-1}\right)$ & 2.00 \\
Sodium $\left(\mathrm{mg} \mathrm{L}^{-1}\right)$ & 1.00 \\
Calcium $\left(\mathrm{mg} \mathrm{L}^{-1}\right)$ & 2.25 \\
Magnesium (mg L-1) & 0.95 \\
Cooper $\left(\mathrm{mg} \mathrm{L}^{-1}\right)$ & 12.50 \\
Znc $\left(\mathrm{mg} \mathrm{L}^{-1}\right)$ & 76.50 \\
Iron (mg L-1) & 75.00 \\
Manganes e $\left(\mathrm{mg} \mathrm{L}^{-1}\right)$ & 16.50 \\
Fixed solids (mg L-1) & 729.00 \\
Settleable solids (mg L-1 $)$ & 6.50 \\
Total solids (mg L-1) & 1.481 .00 \\
Volatile total solids $\left(\mathrm{mg} \mathrm{L}^{-1}\right)$ & 671.00 \\
\hline
\end{tabular}

After applying the ARS, the babycorn sowing was manually performed in conservation tillage (variety BR 106 - Embrapa Maize and Sorghum) on October 13, 2008, at $0.50 \mathrm{~m}$ spacing between rows and $0.08 \mathrm{~m}$ between plants at $0.04 \mathrm{~m}$ depth.

The emergence occured seven days after sowing (DAS). In the vegetative growth stage (ii) with three fully expanded leaves manual thinning was performed at 12 DAS to adjust the population to 180.000 plants per hectare, density of 10 plants per linear meter.

When the appearance of female inflorescence, stage R1, the leaves located opposite and below of the first spike were removed for the purpose of foliage analysis from three plants per plot, considering the middle third, excluding the midrib (Malavolta et al., 1997). The determination of N, P, K, Ca, Mg, $\mathrm{S}, \mathrm{Cu}, \mathrm{Zn}, \mathrm{Mn}$ and $\mathrm{Fe}$ followed the methodology proposed by Tedesco et al. (1995), Laboratory of Environmental Sanitation (Lasam), Center of Exact Sciences and Technology at the State University of West Paraná - Campus of Cascavel. Growth variables were evaluated in three plants per plot from the dawn of the fourth leaf developed to the end of the crop cycle, called as dolled up in case of the babycorn, totaling seven observations in which plant height (EP), vertical distance between soil surface and the highest part of the plant, number of leaves developed per plant $\left(\mathrm{NF} \mathrm{P}^{-1}\right)$, leaf area (LA) length by width of leaf product multiplied by a 0.75 factor (Stickler et al., 1961), leaf area index (LAI) - ratio between photosynthetic active leaf area and the land surface area occupied by the plant, absolute growth rate (AGR) - ratio between height and time between two successive samplings.

After testing for normality and homogeneity of variances (Minitab $\left.{ }^{\circledast} 14\right)$, parameters that showed no normal distribution suffered changes, and then were subjected to analysis of variance $\left(\right.$ Sisvar $\left.^{\circledR}\right)$ (Ferreira, 2000) and when there was 5\% probability, the regression analysis was performed.

\section{RESULTS AND DISCUSSION}

\section{Foliar concentrations of macro and micronutrients}

Summaries of the analysis of variance for foliar concentrations of macro and micronutrients of maize crop under swine wastewater treatment in exclusive application combined with chemical fertilizer are presented in Tables 3 and 4, in which the occurrence of significant effects and interaction between ARS $\mathrm{x} A D$ are observed only for $\mathrm{N}$ and $\mathrm{P}$.

Table 3. $F$ Values and factors and overall average of swine wastew ater and chemical fertilization on the macronutrient contents $\left(\mathrm{g} \mathrm{kg}^{-1}\right)$ in babycorn leaves

\begin{tabular}{lcccccc}
\hline \multicolumn{1}{c}{ Variation } & \multicolumn{7}{c}{$\mathbf{F}$ values } \\
\cline { 2 - 7 } \multicolumn{1}{c}{ causes } & $\mathbf{N}$ & $\mathbf{P}$ & $\mathbf{K}$ & $\mathbf{C a}$ & $\mathbf{M g}$ & $\mathbf{S}$ \\
$\mathrm{ARS}$ & $17.16^{*}$ & $4.12^{*}$ & $4.11^{*}$ & $1.03^{\text {ns }}$ & $6.09^{*}$ & $2.29^{\text {ns }}$ \\
$\mathrm{AD}$ & $3.54^{\text {ns }}$ & $0.77^{\text {ns }}$ & $1.13^{\text {ns }}$ & $0.54^{\text {ns }}$ & $0.18^{\text {ns }}$ & $0.38^{\text {ns }}$ \\
ARS $\times$ AD & $2.91^{*}$ & $3.30^{*}$ & $0.07^{\text {ns }}$ & $0.06^{\text {ns }}$ & $1.01^{\text {ns }}$ & $0.11^{\text {ns }}$ \\
\hline Overall average & 16.23 & 4.13 & 11.27 & 6.76 & 2.58 & 3.61 \\
\hline
\end{tabular}

ARS: Swine wastewater; AD = fertilization; ns: not significant at $5 \%$ probability, ${ }^{*}$ significant at $5 \%$ probability. For the variables normalization values were transformed by $\sqrt{x+1}$, except for $\mathrm{K}$ and Ca (data normality - Shapiro Wilk test and homoscedasticity)

The average contents (Table 3 ) of $\mathrm{N}$ and $\mathrm{K}$ are below levels considered adequate for maize ( 27.5 to $32.5 \mathrm{~g} \mathrm{~kg}^{-1}$ and 17.5 to $22.5 \mathrm{~g} \mathrm{~kg}^{-1}$, respectively) and the nutrients $\mathrm{P}, \mathrm{Ca}, \mathrm{Mg}$ and $\mathrm{S}$ are much higher than the appropriate values (2.5 to $3.5,2.5$ to 4.0 , 
Table 4. Values and factors and overall average of swine wastewater and chemical fertilization on the micronutrient contents $\left(\mathrm{mg} \mathrm{kg}^{-1}\right)$ in babycorn leaves

\begin{tabular}{lcccc}
\hline \multicolumn{1}{c}{ Variation } & \multicolumn{4}{c}{ F values } \\
\cline { 2 - 5 } causes & $\mathbf{C u}$ & $\mathbf{Z n}$ & $\mathbf{M n}$ & $\mathbf{F e}$ \\
$\mathrm{ARS}$ & $0.780^{\text {ns }}$ & $0.49^{\text {ns }}$ & $8.10^{*}$ & $3.22^{*}$ \\
$\mathrm{ARS} \times \mathrm{AD}$ & $0.009^{\text {ns }}$ & $0.18^{\text {ns }}$ & $3.91^{\text {ns }}$ & $0.44^{\text {ns }}$ \\
\hline Overall average & $0.960^{\text {ns }}$ & $0.05^{\text {ns }}$ & $2.07^{\text {ns }}$ & $1.95^{\text {ns }}$ \\
\hline
\end{tabular}

ARS: Swine wastewater; $A D=$ fertilization; ns: not significant at $5 \%$ probability, $*$ significant at $5 \%$ probability. For the variables normalization values were transformed by $\sqrt{x+1}$, except for $\mathrm{Mn}$ e Fe (data normality - Shapiro Wilk test and homoscedasticity)

2.5 to 4,0 and 1.0 to $2.0 \mathrm{~g} \mathrm{~kg}^{-1}$, respectively) (Büll, 1993). Thus, it is possible to infer that the application of ARS and AD was sufficient to meet the nutritional requirements of $\mathrm{P}, \mathrm{Ca}, \mathrm{Mg}$ and $\mathrm{S}$ for babycorn plants.

Prior et al. (2009) evaluated the effect of swine wastewater in soil and corn, for $\mathrm{P}$, the author obtained average contents of $20.80 \mathrm{~g} \mathrm{~kg}^{-1}$, indices below those suitable for P, differing from this work, which has experienced adequate $\mathrm{P}$ levels. This can be explained by the difference of nutrients applied via ARS compared to that of Prior et al. (2009). Still, also by the inflow and phosphorus accumulation and low P mobility in the soil (Costa et al., 2009). In this context, the high mobility of phosphorus in the plant, which, in different availability conditions (Büll, 1993) would provide different answers for $P$ accumulation in the plant, resulting in the $\mathrm{P}$ compartmentalization in shoots.

About two-thirds of the phosphorus in swine liquid manure is insoluble in water, forming organic structures, which provide manure residual effect observed by Ceretta et al. (2005), frequent applications of manure can cause $\mathrm{P}$ accumulation in soil, a fact recorded in this study. Most of the $\mathrm{N}$ available to crops comes from the interaction between nitrogen fertilization and $\mathrm{N}$ mineralization/immobilization from crop residues and $\mathrm{N}$ from soil's organic matter (Silva et al., 2008). Low levels of nitrogen are justified in part due to babycorn crops have been done in succession to black oats, resulting in lower yields of dry matter and lower nitrogen absorption (Aita et al., 2006a), and also due to crop residues with high $\mathrm{C}: \mathrm{N}$ ratio making micro-organisms that work in the organic material decomposition multiply rapidly, assimilating carbon and producing $\mathrm{CO}_{2}$ and parallel to the carbon decomposition need to assimilate $\mathrm{N}$ (Aita et al., 2006b).

The interaction between nitrogen and potassium is antagonistic, since potassium affects nitrate uptake and its reduction in plant tissues (Malavolta et al., 1997). Overall, nitrogen is the nutrient that provides higher productivity increments; however, high applications with no corresponding increase in potassium may result in inappropriate $\mathrm{N}$ : $\mathrm{K}$ ratios within the plant.

Calcium and sulfur contents found in babycorn leaves suffered no influence under treatments with increasing doses of ARS and AD, only similar behavior to $\mathrm{P}$ and $\mathrm{Mg}$, in other words, above the appropriate levels. N:S ratios in the plant between 8 and 12:1 (Malavolta, 2006) are considered ideal, and this work 4 to 7:1 ratios were established. Low ratios may have been caused by increased demand for sulfur-containing amino acids (cysteine, methionine and cystine) when protein synthesis is accelerated by $\mathrm{N}$ supply to the plant (Kalmbacher et al., 2005), providing increased $\mathrm{S}$ concentrations in plant and $\mathrm{N}$ reduction.

Values for micronutrients concentrations (Table 4) lie within the range considered adequate by Büll (1993). According to the author, maize plants should contain 6 to $20 \mathrm{mg} \mathrm{kg}^{-1}, 20$ to 70 $\mathrm{mg} \mathrm{kg}{ }^{-1}, 20$ to $150 \mathrm{mg} \mathrm{kg}^{-1}$ and 20 to $250 \mathrm{mg} \mathrm{kg}^{-1} \mathrm{Cu}, \mathrm{Zn}, \mathrm{Mn}$ and $\mathrm{Fe}$, respectively.

Concentrations of micronutrients in babycorn plants followed the descending order $\mathrm{Fe}>\mathrm{Mn}>\mathrm{Zn}>\mathrm{Cu}$ when sampled. Martins et al. (2003), evaluating the effect of sewage sludge in a single dose and in a piecemeal manner in grain production and absorption of $\mathrm{Cu}, \mathrm{Zn}, \mathrm{Mn}$ and $\mathrm{Fe}$ by maize.

The low values found for $\mathrm{Cu}$ contents can be justified by the high $\mathrm{N}$ supply which reduces the $\mathrm{Cu}$ availability within plants (Kirkby \& Römheld, 2007). Martins et al. (2003), however, found that $\mathrm{Fe}$ and $\mathrm{Mn}$ concentrations were reduced but $\mathrm{Cu}$ concentration remained constant.

Results presented in Figure 1 show that accumulation of nitrogen and phosphorus in babycorn plants had quadractricaly behavior with increasing trend and coefficients of determination $\left(\mathrm{R}^{2}\right) 0.84$ and $0.49\left(\mathrm{y}=0,0001 \mathrm{x}^{2}-0,0152 \mathrm{x}+4,1502\right)$, indicating good and poor relationship between the variables, respectively.
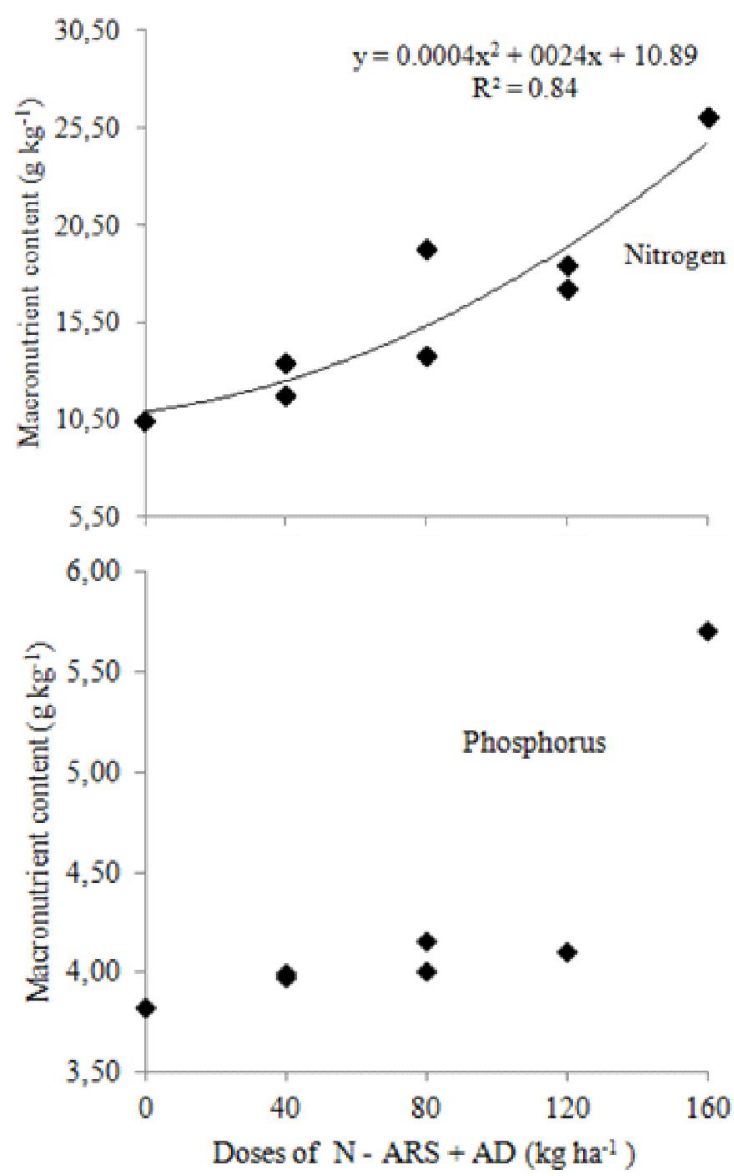

Figure 1. Average accumulation of nitrogen and phosphorus by babycorn leaves according to the application of swine wastewater (ARS) combined with chemical fertilizer (AD) 
The increased levels of ARS application provided increments of nitrogen and phosphorus, as significant values for ARS were found. Plants deficient in nitrogen have lower levels of nitrogen and higher phosphorus, potassium, calcium, magnesium and sulfur contents (Malavolta, 2006).

Concentrations of macronutrients in babycorn plants followed the decreasing order $\mathrm{N}>\mathrm{K}>\mathrm{Ca}>\mathrm{P}>\mathrm{S}>\mathrm{Mg}$. Pinho (2009) evaluated the mineral absorption of nutrients and dry matter accumulation in maize with the following descending order of accumulation in shoot $\mathrm{N}>\mathrm{K}>\mathrm{P}>\mathrm{Ca}>\mathrm{Mg}>\mathrm{S}$. Carmo et al. (2003) evaluated the accumulation of N, P, K, Ca and Mg in maize grown under fertilizer sources, involving liquid swine manure, phosphate rock and gypsum plus NPK by checking the average accumulation of nutrients in descending order $\mathrm{N}>$ $\mathrm{K}>\mathrm{P}>\mathrm{Ca}>\mathrm{Mg}$. The order found by Pinho (2009) was the one that most resembled that observed in this work.

The economic viability of organic waste in the production of corn and soybean grains and probable environmental impact by using swine and poultry waste and observed chemical imbalances observed for phosphorus, copper and zinc nitrate. Phosphorus and magnesium have similar pattern of distribution within the plant with probable mobilization to grains, following the absorption process since $\mathrm{Mg}$ acts as a carrier for $\mathrm{P}$ within the plant and activator of some enzymes of carbohydrate metabolism.

Ferreira et al. (2005) found positive responses to $\mathrm{N}$ application in relation to $\mathrm{Ca}, \mathrm{Mg}, \mathrm{Zn}$ and the $\mathrm{Mox} \mathrm{N}$ interaction showed effect on Fe content.

According to the result observed (Figure 2), the accumulation of manganese and iron in babycorn plants showed a quadratic behavior with decreasing trend for Mn and increasing trend for $\mathrm{Fe}$ and coefficients of determination $\left(\mathrm{R}^{2}\right) 0.97$ and 0.67 , indicating high and good relationship between the variables, respectively.

Fe content was higher than other contents analyzed. This suggests little reduction of nitrite and sulfite, so that nitrate and sulfate are often present at low levels in plants supplied with Fe (Kirkby \& Römheld, 2007).

Soil acidification increases the availability of micronutrients, $\mathrm{Cu}, \mathrm{Mn}, \mathrm{Fe}$ and Zn (Kirkby \& Römheld, 2007), which differed from this study only concerning to levels $\mathrm{Mn}$, since $\mathrm{Cu}, \mathrm{Zn}$ and $\mathrm{Fe}$ had their concentrations increased.

\section{Growth analysis}

Summaries of the analysis of variance for height of plants (EP) and leaf area (LA) of babycorn under swine wastewater treatment at unique application combined with chemical fertilizer are presented in Table 5. The occurrence of significant effects of the AD x ARS interaction for plant height at $30 \mathrm{DAS}$ and leaf area at 19 DAS (days after sowing) was observed.

Almeida et al. (2005) had baby corn plant heights ranging from 1.53 to $1.91 \mathrm{~m}$. The average taken in the last period of this study was $1.16 \mathrm{~m}$ (Table 5), which may have occurred due to during this period there was little or no rainfall, totaling 249.4 $\mathrm{mm}$ and the average temperature was around $30^{\circ} \mathrm{C}$. Certainly they were not enough to meet the crop needs, which can be grown in areas with rainfall from 300 to $5.000 \mathrm{~mm}$ per year, and the amount of water consumed during the cycle is around 600

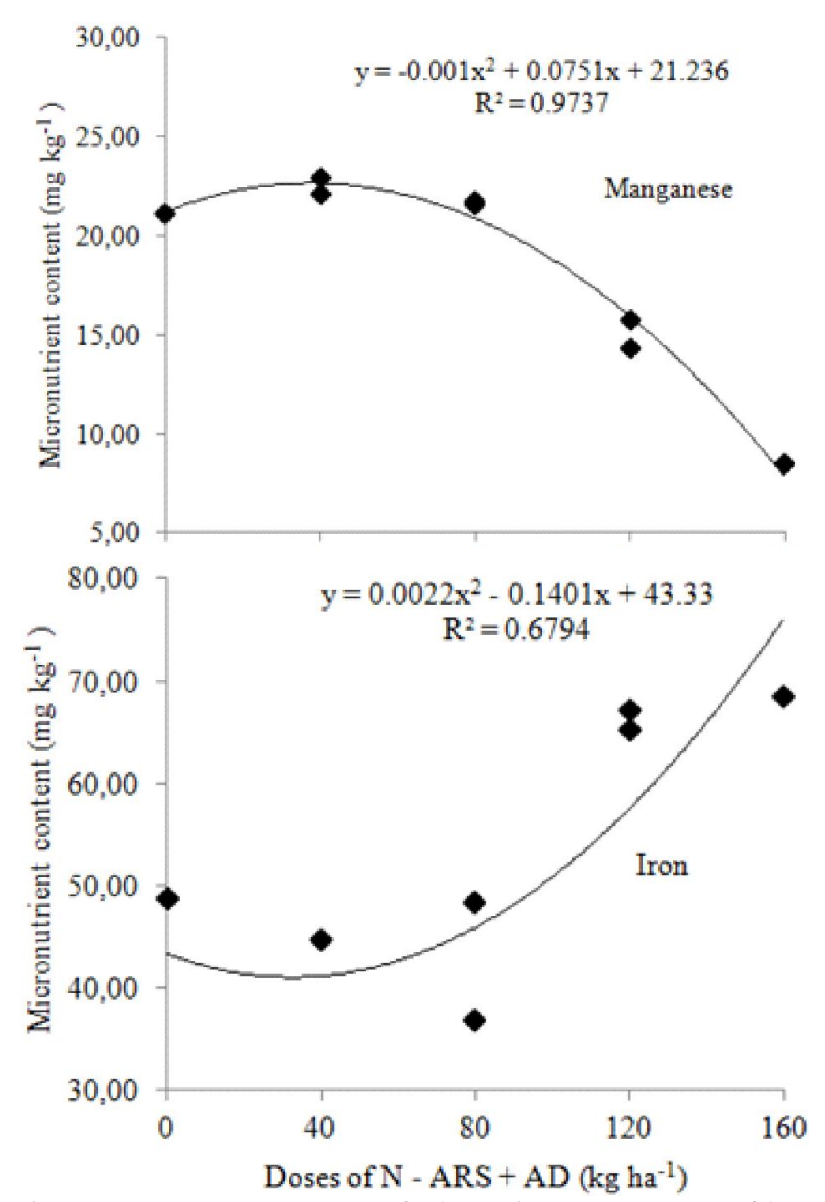

Figura 2. Average accumulation of manganese and iron by leaves of babycorn as function of application of swine wastew ater (ARS) combined with chemical fertilizer (AD)

mm. To Malavolta (2006), plants respond better to daytime temperatures around $25^{\circ} \mathrm{C}$ and night temperatures around 19 ${ }^{\circ} \mathrm{C}$ during the vegetative phase.

Costa et al. (2009) quantified the isolated and joint effects of irrigation with wastewater and biosolids doses on the growth of corn and had leaf area ranging from 0.010 to 0.0193 $\mathrm{m}^{2}$ at 20 DAS and area between 0.582 to $0.827 \mathrm{~cm}^{2}$ at $62 \mathrm{DAS}$, verifying that all maize growth variables were higher for treatments receiving wastewater.

Plant heights (Figure 3) for 30 DAS showed a linear behavior trend with 0.62 coefficient of determination $\left(R^{2}\right)$, whereas the leaf area for 19 DAS showed a quadratic behavior with 0.73 coefficient of determination $\left(\mathrm{R}^{2}\right)$ indicating low relationship between the variables.

The same doses that provided greater heights also promoted greater leaf area. Through the result of regression analysis for height of plants at 30 DAS and leaf area at $19 \mathrm{DAS}$, the $\mathrm{N}$ dose of $160 \mathrm{~kg} \mathrm{ha}^{-1}$ (Treatment 8 to $120 \mathrm{~kg} \mathrm{ha}^{-1}$ ARS and $40 \mathrm{~kg} \mathrm{ha}^{-1}$ $\mathrm{AD})$ promoted higher means for plant height $(0.47 \mathrm{~m})$ and leaf area $\left(0.013 \mathrm{~m}^{2}\right)$.

Summaries of the analysis of variance for leaf area index (LAI), number of leaves per plant $\left(\mathrm{NF}^{-1}\right)$ and absolute growth rate (AGR) of baby corn under swine wastewater treatment at unique application and combined with chemical fertilizer are presented in Table 6. It is observed the occurrence of significant effects of 
Table 5. $F$ values and overall average of swine wastewater and fertilization on the plant height (EP) and leaf area (LA) of babycorn in the observed period

\begin{tabular}{|c|c|c|c|c|c|c|c|}
\hline \multirow{2}{*}{$\begin{array}{l}\text { Variation } \\
\text { causes }\end{array}$} & \multicolumn{7}{|c|}{ Days after sowing } \\
\hline & 19 & 30 & 42 & 54 & 62 & 70 & 75 \\
\hline & \multicolumn{7}{|c|}{$\mathrm{F}$ values for plant height $(\mathrm{m})$} \\
\hline ARS & $4.56^{*}$ & $4.53^{*}$ & $15.76^{*}$ & $24.34 *$ & $32.57^{*}$ & $38.16 *$ & $33.78 *$ \\
\hline$A D$ & $4.69 *$ & $8.64 *$ & $15.04 *$ & $21.63 *$ & $0.61 *$ & $29.61^{*}$ & $27.61 *$ \\
\hline ARS $\times A D$ & $0.31^{\mathrm{ns}}$ & $3.45^{*}$ & $1.59^{\text {ns }}$ & $0.13^{\text {ns }}$ & $1.49^{\text {ns }}$ & $2.18^{\text {ns }}$ & $3.07^{\text {ns }}$ \\
\hline \multirow[t]{2}{*}{ Overall average } & 0.26 & 0.41 & 0.64 & 0.88 & 0.96 & 1.13 & 1.16 \\
\hline & \multicolumn{7}{|c|}{$\mathrm{F}$ values for leaf area $\left(\mathrm{m}^{2}\right)$} \\
\hline ARS & 7.33* & $6.28^{*}$ & $5.43^{*}$ & $14.46^{*}$ & $8.35 *$ & $18.01 *$ & $23.39 *$ \\
\hline$A D$ & $16.75^{*}$ & $3.83^{\text {ns }}$ & $2.77^{*}$ & $12.77 *$ & $6.25^{*}$ & $7.95^{*}$ & $10.67 *$ \\
\hline ARS $\times A D$ & $3.48 *$ & $2.07^{\text {ns }}$ & $0.74^{\text {ns }}$ & $1.55^{\text {ns }}$ & $0.35^{\text {ns }}$ & $0.84^{\text {ns }}$ & $0.083^{\text {ns }}$ \\
\hline Overall average & 0.009 & 0.023 & 0.03 & 0.05 & 0.06 & 0.11 & 0.15 \\
\hline
\end{tabular}

ARS: swine wastewater; AD = fertilization; DAS: Days after sowing; ns: not significant at $5 \%$ probability level, * significant at $5 \%$ probability. Variables showed normal distribution for plant height; for the normalization of variables of leaf area values were transformed by $\sqrt{x+1}$, except for 19 DAS (data normality - Shapiro Wilk test and homoscedasticity)
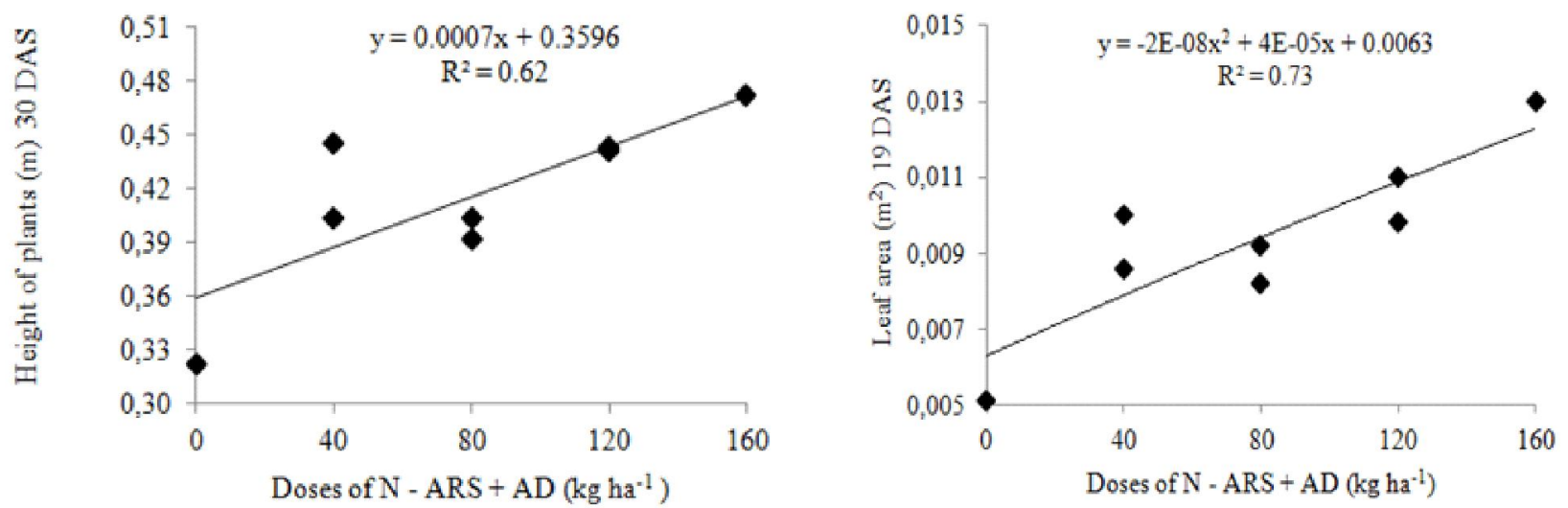

Figura 3. Plants height and leaf area of babycorn as function of differential treatment by ARS levels combined with AD for periods of 30 and 19 DAS

Table 6. $\mathrm{F}$ values and overall average for swine wastew ater and fertilization on the leaf area index (LAI), number of leaves per plant $\left(\mathrm{N} \mathrm{F} \mathrm{plant}{ }^{-1}\right.$ ) and absolute grow th rate (AGR) of babycorn in the observed periods

\begin{tabular}{|c|c|c|c|c|c|c|c|}
\hline \multirow{2}{*}{$\begin{array}{l}\text { Variation } \\
\text { causes }\end{array}$} & \multicolumn{7}{|c|}{ Days after sowing } \\
\hline & 19 & 30 & 42 & 54 & 62 & 70 & 75 \\
\hline & \multicolumn{7}{|c|}{$F$ values for foliar area index $\left(\mathrm{m}^{2} \mathrm{~m}^{-2}\right)$} \\
\hline ARS & $3.67 *$ & $1.17^{*}$ & $7.11^{*}$ & $17.70 *$ & $9.4^{*}$ & $22.75^{*}$ & $30.94 *$ \\
\hline & $13.57^{*}$ & $3.49^{\text {ns }}$ & $0.84^{\mathrm{ns}}$ & $11.71^{*}$ & $6.61 *$ & $9.37 *$ & $13.26 *$ \\
\hline Interaction & $3.51^{*}$ & $2.36^{\mathrm{ns}}$ & $0.72^{\mathrm{ns}}$ & $1.06^{\mathrm{ns}}$ & $0.34^{\text {ns }}$ & $0.73^{\mathrm{ns}}$ & $0.20^{\text {ns }}$ \\
\hline \multirow[t]{2}{*}{ Overall average } & 0.19 & 0.47 & 0.78 & 1.17 & 1.33 & 2.36 & 3.00 \\
\hline & \multicolumn{7}{|c|}{$\mathrm{F}$ values for number of leaves per plant } \\
\hline ARS & $4.81 *$ & $3.57 *$ & $5.24 *$ & $16.25^{*}$ & $6.63^{*}$ & $21.91 *$ & $15.95 *$ \\
\hline$A D$ & $9.29 *$ & $6.29 *$ & $0.98^{\mathrm{ns}}$ & $2.92^{\text {ns }}$ & $0.92 *$ & $21.60 *$ & $14.19 *$ \\
\hline Interaction & $1.72^{\mathrm{ns}}$ & $1.89^{\text {ns }}$ & $0.52^{\mathrm{ns}}$ & $0.65^{\mathrm{ns}}$ & $0.43^{\text {ns }}$ & $0.74^{\mathrm{ns}}$ & $0.33^{\text {ns }}$ \\
\hline \multirow[t]{3}{*}{ Overall average } & 6.00 & 7.33 & 8.90 & 9.91 & 10.23 & 10.73 & 12.08 \\
\hline & \multicolumn{7}{|c|}{$F$ values for absolute growth rate $\left(\mathrm{m} \mathrm{d}^{-1}\right)$} \\
\hline & TCA 11 & TCA 12 & TCA 12 & & TCA 8 & TCA 8 & TCA 5 \\
\hline ARS & $0.16^{\text {ns }}$ & $11.77^{*}$ & $6.09 *$ & & $3.43^{*}$ & $8.45^{*}$ & $2.56^{\mathrm{ns}}$ \\
\hline$A D$ & $4.25^{*}$ & $5.83^{*}$ & $3.17^{\text {ns }}$ & & $3.57^{\text {ns }}$ & $2.59^{\text {ns }}$ & $0.071^{\text {ns }}$ \\
\hline Interaction & $3.66^{*}$ & $3.53^{*}$ & $1.65^{\text {ns }}$ & & $2.52^{\text {ns }}$ & $1.22^{\text {ns }}$ & $2.57^{\text {ns }}$ \\
\hline Overall average & 0.013 & 0.019 & 0.019 & & 0.010 & 0.020 & 0.0076 \\
\hline
\end{tabular}

ARS: Swine wastewater; AD = fertilization; DAS: Days after sowing; ns: not significant at 5\% probability level, * significant at $5 \%$ probability. For normalization of variables for foliar area index and absolute growth rate values were transformed to $\sqrt{x+1}$, except for 19 DAS (data normality - Shapiro Wilk test and homoscedasticity). For number of leaves per plant variables showed normal distribution

the interaction ARS x AD on the leaf area index at 19DAS and absolute growth rate in the first and second observation.

Sá et al. (2002) obtained values around 3.18 and $3.63 \mathrm{~m}^{2}$ for LAI in analysis to morphological and physiological aspects of modern and old cultivars of corn, approaching to the maximum values of this study ( 3.41 to $4.55 \mathrm{~m}^{2} \mathrm{~m}^{-2}$ ).

Almeida et al. (2005) for a population of 178,570 plants obtained the number of leaves ranging from 8 to 14 per plant, 
and also above the values of Meneghetti et al. (2008a,b), evaluating water irrigation in babycorn, obtaining values between 12.32 and 12.85 leaves per plant.

Figure 4 shows the leaf area index and absolute growth rate of babycorn in the treatments with ARS levels in combination with $\mathrm{AD}$ for periods of 19 days after sowing and 11 and 12 days of observation, and coefficients of determination $\left(R^{2}\right) 0.79$ and $0.49\left(\mathrm{y}=0,0118 \mathrm{e}^{0.0055 \mathrm{x}}\right)$ for 12 days, and $0,40\left(\mathrm{y}=0,0099 \mathrm{e}^{0.0034 \mathrm{x}}\right)$, for 11 days, indicating good and low relationship between the variables, respectively.

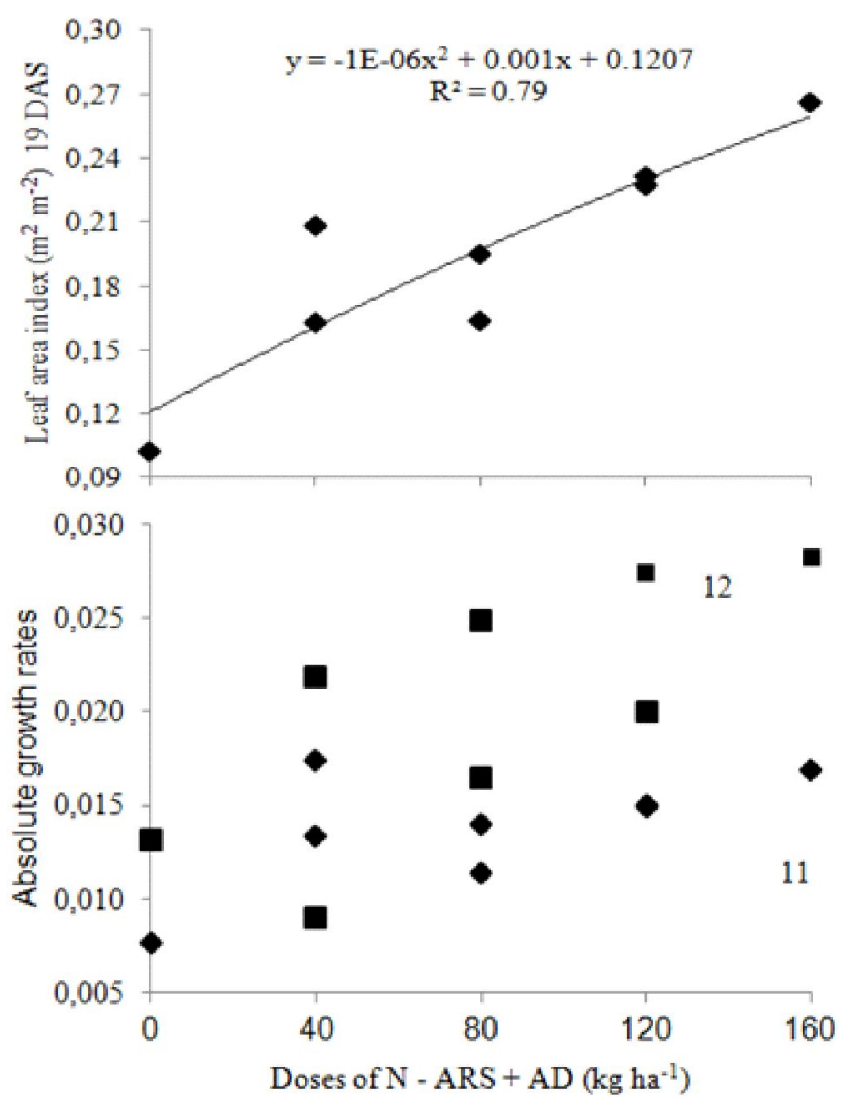

Figura 4. Leaf area index and absolute growth rate as function of the differential treatment by ARS levels combined with AD for periods of 19 DAS and 11 and 12 days of observation

Equally to the leaf area (LA), the leaf area index (LAI) of babycorn for 19 DAS showed a quadratic behavior with a growing trend and 0.79 coefficient of determination $\left(\mathrm{R}^{2}\right)$. The absolute growth rate (TCA) for 11 and 12 days of observation showed exponential behavior and coefficients of determination $\left(\mathrm{R}^{2}\right)$ of 0.49 and 0.40 , which indicates low relationship between variables.

\section{Conclusions}

1. Swine wastewater doses are less than $120 \mathrm{~kg} \mathrm{ha}^{-1}$, since the systematic use increase nutrient levels of plant $(\mathrm{P}, \mathrm{Ca}, \mathrm{Mg}$ and $\mathrm{S}$ ), which can reach levels above those recommended, suggesting accumulation.
2. The application depends on the nitrogen concentration in the swine wastewater, fact not considered by the farmer, once it references always the volume of application and not the concentration.

\section{LITERATURE CITED}

Aita, C.; Chiapinotto, I. C.; Giacomini, S. J.; Hübner, A. P.; Marques, M. G. Decomposição de palha de aveia preta e dejetos de suínos em solo sob plantio direto. Revista Brasileira de Ciência do Solo, v.30, p.149-161, 2006a.

Aita, C.; Port, O.; Giacomini, S. J. Dinâmica do nitrogênio no solo e produção de fitomassa por plantas de cobertura no outono/inverno com o uso de dejetos de suínos. Revista Brasileira de Ciência do Solo, v.30, p.901-910, 2006 b.

Almeida, I. P. C.; Silva, P. S. L.; Negreiros, M. Z.; Barbosa, Z. Baby corn, green ear, and grain yield of corn cultivars. Horticultura Brasileira, v.23, p.960-964, 2005.

Büll, L. T. Nutrição mineral do milho. In: Büll, L. T.; Cantarella, H. Cultura do milho: Fatores que afetam a produtividade. Piracicaba: Associação Brasileira para Pesquisa da Potassa e do Fosfato, 1993. p.63-145.

Carmo, C. A. F. de S. do; Meneguelli, N. do A.; Macedo, J. R. de; Capeche, C. L.; Melo, A. da S.; Silva, E. F. da. Acúmulo de nutrientes em milho cultivado em nitossolo degradado sob diferentes fontes de adubação. Magistra, v.15, p.129140, 2003.

Ceretta, C. A.; Basso, C. J.; Vieira, F. C. B.; Herbes, M. G.; Moreira, I. C. L.; Berwanger, A. L. Dejeto líquido de suínos: I- Perdas de nitrogênio e fósforo na solução escoada do solo, sob plantio direto. Ciência Rural, v.35, p.1296-1304, 2005.

Costa, F. X.; Lima, V. 1. A. de; Beltrão, N. E. de M.; Azevedo, C. A. V. de; Soares, F. A. L.; Alva, I. D. M. Efeitos residuais de aplicação de biossólidos e da irrigação com água residuária no crescimento do milho. Revista Brasileira de Engenharia Agrícola e Ambiental, v.13, p.687-693, 2009.

Durigon, R.; Ceretta, C. A.; Basso, C. J.; Barcellos, L. A. R.; Pavinato, P. S. Produção de forragem em pastagem natural com o uso de esterco líquido de suíno. Revista Brasileira de Ciência do Solo, v.22, p.983-992, 2002.

EMBRAPA - Empresa Brasileira De Pesquisa Agropecuária. Centro Nacional de Pesquisa de Solos. Sistema brasileiro de classificação de solos. 2.ed. Rio de Janeiro: Embrapa Solos. 2006. 306p.

Ferreira, D. F. Manual do sistema Sisvar para análises estatísticas. Lavras: UFLA, 2000. 66p.

Ferreira, O. E.; Beltrão, N. E. de M.; König, A. Efeitos da aplicação de água residuária e nitrogênio sobre o crescimento e produção do algodão herbáceo. Revista Brasileira de Oleaginosas e Fibrosas, v.9, p.893-902, 2005.

Kalmbacher, R. S.; Ezenwa, I. V.; Arthington, J. D.; Martin, F. G. Sulfur fertilization of Bahiagrass with varying levels of nitrogen fertilization on a Florida Spodosol. Agronomy Journal, v.97, p.661-667, 2005. 
Kirkby, E. A.; Römheld, V. Micronutrientes na fisiologia de plantas: funções, absorção e mobilidade. Informações Agronômicas 118. INPI, 2007. 24p. Encarte Técnico

Malavolta, E. Manual de nutrição mineral de plantas. São Paulo: Agronômica Ceres, 2006. 631p.

Malavolta, E.; Vitti, G. C.; Oliveira, S. A. Avaliação do estado nutricional das plantas. 2.ed. Potafos: Piracicaba. 1997.319p.

Martins, A. L. C.; Bataglia, O. C.; Camargo, O. A.; Cantarella, H. Produção de grãos e absorção de $\mathrm{Cu}, \mathrm{Fe}, \mathrm{Mn}$ e $\mathrm{Zn}$ pelo milho em solo adubado com lodo de esgoto, com e sem calcário. Revista Brasileira de Ciência do Solo, v.27, p.563574, 2003.

Meneghetti, A. M.; Nóbrega, L. H. P.; Santos, R. F. Manejo da irrigação para a produção de minimilho por evapotranspiração. Engenharia na Agricultura, v.16, 351358, 2008a.

Meneghetti, A. M.; Santos, R. F.; Nóbrega, L. H. P.; Martins, G. I. Análise de crescimento de minimilho submetido a lâminas de irrigação. Acta Scientiarum Agronomy, v.30, p.211-216, 2008b.

Pandolfo, C. M.; Ceretta, C. A.; Massignam, A. M.; Veiga, M. da; Moreira, C. L. Análise ambiental do uso de fontes de nutrientes associadas a sistemas de manejo do solo. Revista Brasileira de Engenharia Agrícola Ambiental, v.12, p.543550,2008 .

Pinho, R. G.; Borges, I. D.; Andrade, J. L. de; Rezende, P.; Reis, M. C. dos. Marcha de absorção de macronutrientes e acúmulo de matéria seca em milho. Revista Brasileira de Milhoe Sorgo, v.8, p.157-173, 2009.
Prior, M.; Smanhotto, A. Sampaio, S. C.; Nóbrega, L. H. P.; Opazo, M. A. U.; Dieter, J. Acúmulo e percolação de fósforo no solo devido à aplicação de água residuária de suinocultura na cultura do milho (Zea mays L.). Pesquisa Aplicada e Agrotecnologia, v.2, p.89-96, 2009.

Sá, M.; Ramalho, M. A. P.; Souza Sobrinho, F. de. Aspectos morfológicos e fisiológicos de cultivares modernas e antigas de milho. Ciências e Agrotecnologia, v.26, p.1082-1091, 2002.

Seidel, E. P.; Gonçalves Júnior, A. C.; Vanin, L. S.; Schwantes, D. Nacke, H. Aplicação de dejetos de suínos na cultura de milho cultivado em sistema de plantio direto. Acta Scientiarum. Technology, v.32, p.113-117, 2010.

Silva, E. C. da; Muraoka, T.; Buzetti, S.; Contreras, S. F.; Trivelin, P. C. O. Utilização do nitrogênio da palha de milho e adubos verdes pela cultura do milho. Revista Brasileira de Ciência do Solo, v.32, p.2853-2861, 2008.

Smanhotto, A.; Sousa, A. de P.; Sampaio, S. C.; Nóbrega, L. H. P.; Prior, M.; Cobre e zinco no material percolado e no solo com a aplicação de água residuária de suinocultura em solo cultivado com soja. EngenhariaAgrícola, v.30, p.347-357, 2010.

Stickler, F. C.; Wearden, S.; Pauli, A. W. Leaf area determination in grain sorghum. Agronomy Journal, v.53, p.187-188, 1961.

Tedesco, M. J.; Gianello, C.; Bissani, C. A.; Bohenen, H.; Volkweiss, S. J. Análise de solo, plantas e outros materiais. Porto Alegre: UFRGS, 1995. 174p.

Vasconcellos, C. A.; Alves, V. M. C.; Pereira Filho, I. A.; Pitta, G. V. E. Nutrição e adubação do milho visando obtenção do minimilho. Sete Lagoas: Embrapa Milho e Sorgo, 2001. 6p. Circular Técnica 9. 